\title{
Improvement of Students' Mathematics Results through ICARE Learning Model by Implementing the Concept Map
}

\author{
Reskiah $^{1,{ }^{*}}$, Ashari $^{1}$, Fatimah $^{1}$, Hari Aningrawati Bahri ${ }^{1}$, Basri $^{2}$ \\ ${ }^{1}$ Mathematics Education, Universitas Al Asyariah Mandar, Indonesia \\ ${ }^{2}$ Informatics Study Program, Universitas Al Asyariah Mandar, Indonesia
}

Received December 7, 2019; Revised January 8, 2020; Accepted January 13, 2020

Copyright $\mathrm{C} 2020$ by authors, all rights reserved. Authors agree that this article remains permanently open access under the terms of the Creative Commons Attribution License 4.0 International License

\begin{abstract}
This study aims to find out how to improve students' mathematics learning outcomes through the ICARE learning model by applying the concept map to students of SMP Negeri 1 Wonomulyo with a population of 211 people, consisting of 7 classes. The sample of this study was 36 people, namely class 8B of State Junior High School 1 Wonomulyo. The research instrument used was a learning achievement test, student activity sheets, and learning achievement sheets. Data analysis uses descriptive and inferential statistical analysis and there are few category that used in the research to show how ICARE learning model can improve student passion in mathematic learning. The results showed that students' learning outcomes in mathematics taught by the ICARE learning model with the application of the concept map, provides opportunities for students to exchange ideas with friends or teachers in terms of finding and building their own knowledge in students, wherewith these conditions create positive responses in mathematics learning. Analysis in multi graph for each category and correspondence show that student perspective in mathematic learning improve significance.
\end{abstract}

Keywords Improvement, ICARE, Concept Maps, Student Learning Outcomes

\section{Introduction}

The curriculum in Indonesia, Mathematics is one of the fields of study that is studied explicitly starting from the level of kindergarten to college. The critical role of mathematics was recognized by Cockcroft in [1] who states that "it would be challenging perhaps impossible to live a normal life in very many parts of the world in the twentieth century without making use of the mathematics of some kind." This statement shows that the importance of mathematics in life that even something so difficult [2], would not also be possible to live a normal life, without using mathematical methods. Based on observations made in class 8 of State Junior High School 1 Wonomulyo Polewali Mandar, information is obtained that the average students' mathematics learning outcomes in each daily test given by the teacher is still deficient, reaching only 69 just below the KKM (the lowest criterion to state students' achieving mastery in Indonesia education system) set by the school, 65 . The teacher revealed several problems experienced in the process of learning mathematics in schools [3], namely: (1) when the process of learning mathematics takes place, students' attention is not focused, students consider mathematics is a difficult subject which can be seen from how low the results of daily tests are (2) student's motivation to learn is still low, (3) students are less active in the teaching and learning process, and only two or three students dare to ask and answer teacher questions [4].

Based on the problems, innovation and efforts are needed to be done in learning mathematics. Roestiyah in [5] said that in the learning process, the learners themselves are actively building their knowledge, while the instructor (teacher) acts as a mediator, facilitator, guide, by providing opportunities for students to find and apply their ideas to enhance the activeness of students' roles in learning. For this reason, the teacher is expected to design a learning model that can make students to build their own knowledge [6], increase students' enthusiasm for learning mathematics, make students more active in learning, direct students to draw conclusions from the lessons given, so that learning becomes more meaningful, and students can capture the core of education [7], although it must be initiated by a good entrance selection system [8]. Therefore, it is needed a mathematics learning model so that students are active in the teaching and learning process to which the ICARE learning model with a concept map 
becomes one of the solutions as for the ICARE Learning Model Phase as follows [9]:

Table 1. Phase of the ICARE Learning Model

\begin{tabular}{|l|l|}
\hline Phase & Description \\
\hline \multirow{5}{*}{ Introduction } & $\begin{array}{l}\text { This learning phase consists of: } \\
\text { - Context }\end{array}$ \\
$\begin{array}{l}\text { - Purpose } \\
\text { Prerequisite }\end{array}$ \\
\hline Connect or Content & $\begin{array}{l}\text { Connecting subject matter with basic } \\
\text { concepts, learning resources or students' } \\
\text { initial understanding. }\end{array}$ \\
\hline Apply All activities & $\begin{array}{l}\text { Exercise, problem-solving and others are } \\
\text { applied in this phase }\end{array}$ \\
\hline \multirow{3}{*}{ Reflect } & $\begin{array}{l}\text { This phase provides an opportunity for } \\
\text { students to reflect on the knowledge } \\
\text { gained and articulate their experiences. }\end{array}$ \\
\hline Extend & $\begin{array}{l}\text { The incorporation of all previous phases } \\
\text { that offers learning materials and } \\
\text { opportunities that are improved extended, } \\
\text { or advanced, depending on student } \\
\text { performance }\end{array}$ \\
\hline
\end{tabular}

Erman Suherman in [10] stated that learning with the application of concept maps is a meaningful relationship between one concept and another concept that is connected by words to form a significant proposition where the objectives to be achieved in this study are: to find out the effectiveness of ICARE learning model by applying concept maps to students' mathematics learning outcomes [11]. Vanides in [12] states four steps of implementation in class, which are:

1. Step 1: Each student is asked to list or arrange the concepts contained in a topic simply according to their abilities.

2. Step 2: Next the students are asked to connect the concepts that they have arranged before

3. Step 3: Review the concept map that each student has made in a small group.

4. Step 4: Discuss the concept map that was reviewed in the small group with other groups to get the correct concept map.

\section{Materials and Methods}

This type of research used in this research is Classroom Action Research (CAR) which only involves one class to implement the ICARE learning model with the application of a concept map where the number of meetings was held eight times in 2 cycles. Before the implementation was done a pretest was given and after the implementation then a post-test also is given. The population in this study was all students of class $8 \mathrm{~B}$ of State Junior High School 1 Wonomulyo with the assumption that the ability of each class was the same (homogeneous), so the sampling technique used was simple random sampling technique, and obtained class $8 \mathrm{~B}$ as samples of object research. Based on the initial reflection, Classroom Action Research is carried out in two cycles, namely Cycle I and Cycle II, which start from the planning, action, observation and evaluation and reflection stages. The descriptions of activities carried out in the implementation of CAR in this study are as follows:

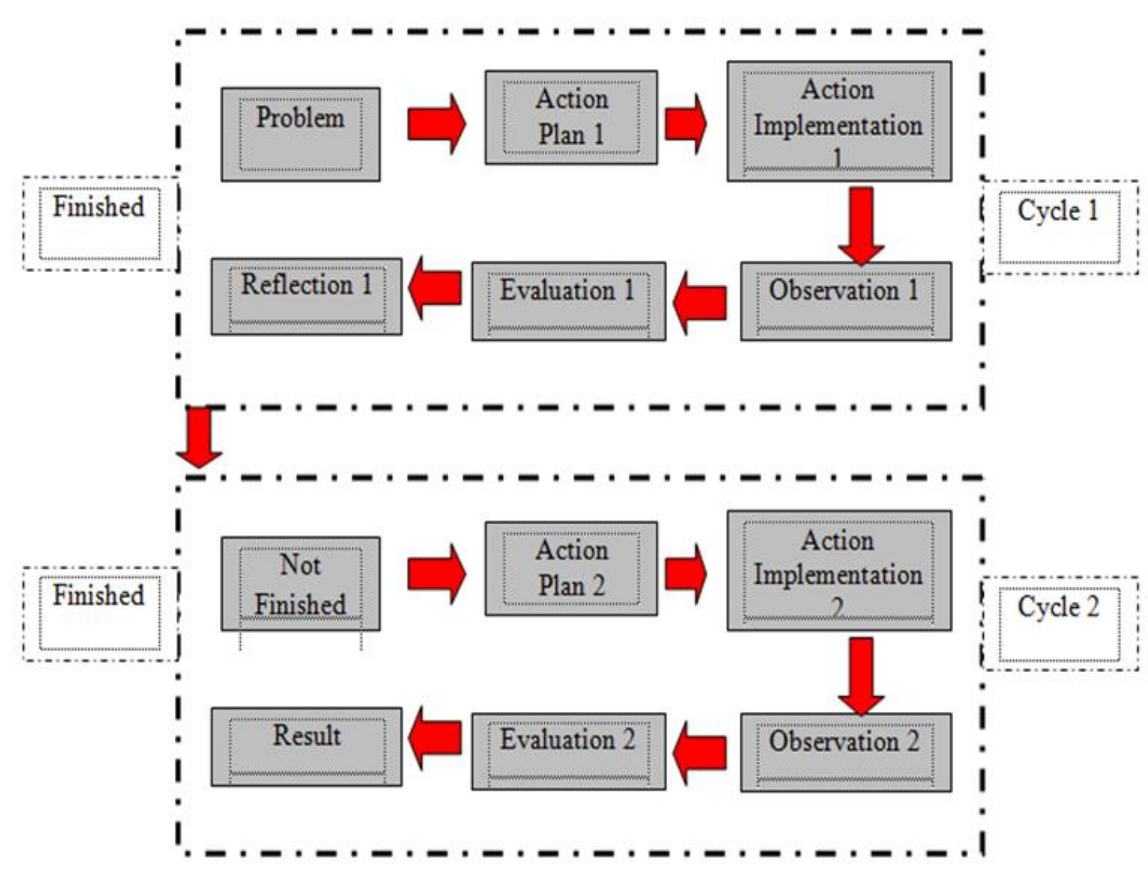

Figure 1. CAR Design [13] 
The research instruments used in this study were observation sheets, and tests Observation sheet consists of two kinds, they are student activity observation sheet to find out student activities and observation sheet of the implementation of learning models to find out how well the implementation of the learning model when learning takes place, while the test pointed here is a test of learning outcomes used to determine the learning outcomes obtained by students after participating in learning activities using the ICARE learning model with the application of concept maps. Student mathematics learning outcomes data were analyzed using category five, namely: $85-100$ categorized as "very high", 65-84 categorized as "high", 55-64 categorized as "moderate", 35-54 categorized as "low", 0-34 categorized as "very low". Data on student activity was obtained using student activity observation sheets in ICARE learning with the implementation of concept maps as an effective method for student achievement progress [14], [15]. Data on student learning outcomes were collected using student learning outcome tests. Data on the feasibility of the learning model was collected using an observation sheet of learning model implementation.

\section{Results and Discussion}

\subsection{Initial Stage Research Results}

Activities carried out in the pre-research stage by implementing the ICARE learning model with the implementation of the concept map are the implementation of the initial test to determine the initial abilities of Class 8B students at State Junior High School 1 Wonomulyo. The results obtained from the initial stages of the research are quantitative analysis data in the form of student mathematics learning outcomes in Table 2 below:

Table 2. Statistics on Learning Outcomes of Class $8 \mathrm{~B}$ students of State Junior High School Wonomulyo on the initial test

\begin{tabular}{|c|c|c|}
\hline \multirow{2}{*}{$\mathrm{N}$} & & Initial test \\
\cline { 2 - 3 } & Valid & 36 \\
\cline { 2 - 3 } & Missing & 0 \\
\hline Mean & & 41,1667 \\
\hline Median & & 40,0000 \\
\hline Mode & & 60,00 \\
\hline Std. Deviation & & 19,29989 \\
\hline Variance & & 372,486 \\
\hline Range & & 60,00 \\
\hline Minimum & & 13,00 \\
\hline Maximum & & 73,00 \\
\hline Sum & & 1482,00 \\
\hline
\end{tabular}

The average value of the learning outcomes obtained from 36 students on the initial test was 41.17 which means that the average absorptive capacity of Class $8 \mathrm{~B}$ students at State Junior High School 1 Wonomulyo in receiving mathematics subject before the application of learning with ICARE learning models with concept maps are in the low and uncompleted categories. The result of the mode value is 60 which can be concluded that most of the students' scores are in a low grade. And the result of the standard deviation value is 19.29 .

Frequency distribution and the percentage of types of student learning outcomes after data grouping of the mathematics learning outcome scores achieved in the initial test into category five, a list of the then obtained as shown in full in Table 3.

Table 3. Distribution and Percentage of Students' Learning Outcomes in Class 8 B of Junior High School 1 Wonomulyo on the Initial Test

\begin{tabular}{|c|c|c|c|c|}
\hline \multirow{2}{*}{ No } & \multirow{2}{*}{ Score } & Category & \multicolumn{2}{|c|}{ Initial Test } \\
\cline { 4 - 5 } & & & Frequency & $\begin{array}{c}\text { Percentage } \\
(\%)\end{array}$ \\
\hline 1 & $0-34$ & Very Low & 17 & 47,22 \\
\hline 2 & $35-54$ & Low & 4 & 11,20 \\
\hline 3 & $55-64$ & Moderate & 13 & 36,10 \\
\hline 4 & $65-84$ & High & 2 & 5,60 \\
\hline 5 & $85-100$ & Very High & 0 & 0,00 \\
\hline \multicolumn{3}{|c|}{ Total } & $\mathbf{3 6}$ & $\mathbf{1 0 0 \%}$ \\
\hline
\end{tabular}

The frequency and percentage of test scores of mathematics learning outcomes for students of class 8B State Junior High School 1 Wonomulyo at the time before the study was conducted for more details could be seen in the graph.

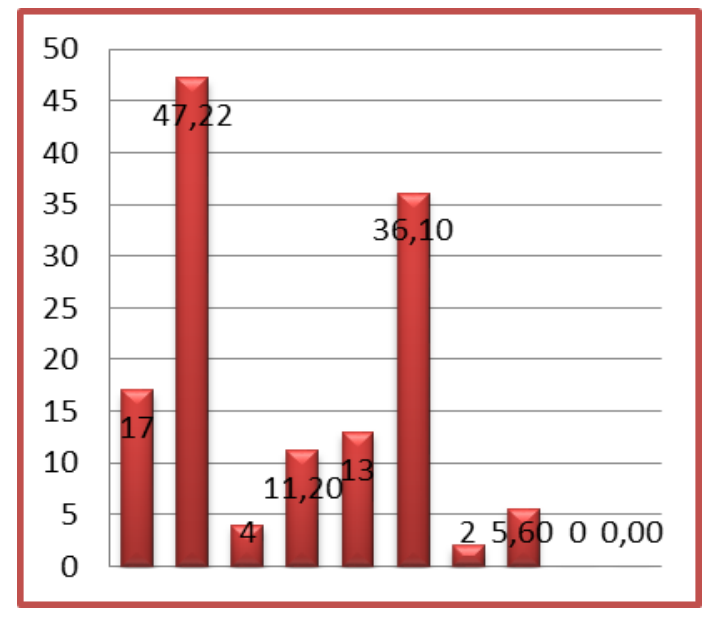

Figure 2. Test scores of mathematics learning outcomes before the study

From Fig. 2. it appears that there are 17 people (47.22\%) who entered the deficient category before the study, the number of students who were in the low category before the study there were 4 people $(11.20 \%)$, the number of students who were included in the moderate category at the time before the survey as many as 13 people $(36.10 \%)$, while students who were in the high category were 2 people 
$(5.60 \%)$ at the time before the study, as well as in the very high category there were no students $(0 \%)$ at the time before research.

Furthermore, to see the achieving mastery level of students' learning, the overall scores obtained from students are divided into two interval values in the category of mastery learning level that applied in State Junior High School 1 Wonomulyo for Mathematics Subject. The percentage and category of mastery learning level for students of class 8B State Junior High School 1 Wonomulyo can be seen in the Figure. 3 as follow:

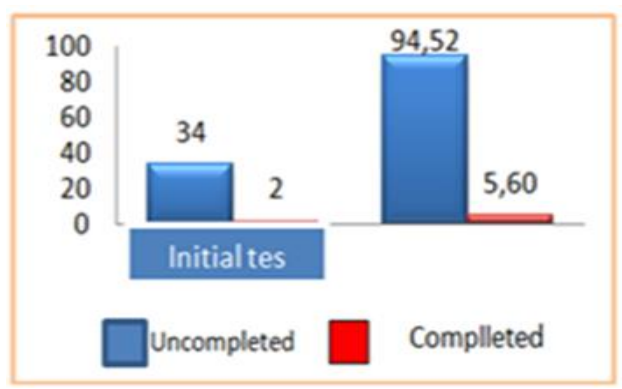

Figure 3. Percentage and mastery learning category of Mathematics learning scores of students class 8B State Junior High School 1 Wonomulyo before research

This shows that the learning outcomes of mathematics achieved by students of class 8B State Junior High School 1 Wonomulyo in the condition of learning without a model is on average still below the value of the Minimum Mastery Criteria (KKM) used in State Junior High School 1 Wonomulyo that is equal to 65 . This result is following the problems described in the background of the problem.

\subsection{Research Results of Cycle I and Cycle II}

\subsubsection{Discussion of Observation Data Result in Cycle I and Cycle II}

\subsubsection{Student Activity Data}

Student activity data obtained through the observation instrument of student activity conducted during the learning process. Student activity indicators consist of 8 aspects of observation based on the learning characteristics applied.

Observation is carried out by observing each student's activity based on the instructions on the observation instrument carried out at each meeting. Data obtained from these instruments are summarized at the end of each session. Meanwhile, the average scores of student activities that are converted based on the rubric of student activity assessment and recapitulation of student activities based on the aspect categories of activities are presented in the following table:
Table 4. Recapitulation of student activities

\begin{tabular}{|c|c|c|c|}
\hline $\begin{array}{c}\text { Observation } \\
\text { Aspect }\end{array}$ & $\begin{array}{l}\text { Cycle I } \\
\text { and II }\end{array}$ & Average score & Category \\
\hline 1 & & 3,62 & Very active \\
\hline 2 & & 3,62 & Very active \\
\hline 3 & & 3,62 & Very active \\
\hline 4 & & 3,56 & Very active \\
\hline 5 & & 3,47 & Very active \\
\hline 6 & & 3,62 & Very active \\
\hline 7 & & 3,62 & Very active \\
\hline 8 & & 0,14 & Not active \\
\hline \multicolumn{2}{|c|}{ Total Average } & 3,59 & Very active \\
\hline
\end{tabular}

Based on the table above, it appears that the average score of student activity is in a very active category. Thus it can be concluded that student activities through ICARE learning with the application of concept maps meet the criteria of improvement descriptively.

\subsubsection{Implementation of ICARE Learning with the Application of Concept Maps}

Data on the Implementation of ICARE Learning with the application of concept maps, as shown in full in Table 5.

Table 5. Observation Results on the Implementation of ICARE Learning by Application of concept map

\begin{tabular}{|c|c|c|c|}
\hline Meeting & Cycle & Average & Category \\
\hline Meeting I & \multirow{4}{*}{ Cycle I } & 4,53 & Very well-implemented \\
\hline Meeting II & & 4,57 & Very well-implemented \\
\hline Meeting III & & 4,34 & Well-implemented \\
\hline Meeting IV & & 4,40 & Well-implemented \\
\hline Meeting V & \multirow{4}{*}{ Cycle II } & 4,53 & Very well-implemented \\
\hline Meeting VI & & 4,61 & Very well-implemented \\
\hline Meeting VII & & 4,61 & Very well-implemented \\
\hline Meeting VIII & & 4,59 & Very well-implemented \\
\hline Total Average & & 4,52 & Well-implemented \\
\hline
\end{tabular}

Based on the results of research on aspects of the implementation of ICARE learning with the application of concept maps, the average implementation of learning is 4.52 in the well-implemented category. The results showed that there was development in the implementation of learning at each meeting. The average implementation of ICARE learning with the application of concept maps. 


\subsubsection{Data on Students' Learning Outcomes in Cycle I and} Cycle II

\subsubsection{Discussion and Presentation of Analysis Results of} Learning Test Data in Cycle I

From the results of the analysis of the Mathematics learning outcomes of Class 8B students of State Junior High School, 1 Wonomulyo in the first cycle test can be seen in the table. 6 below.

Table 6. Learning Outcomes Statistics of Student Class 8B of State Junior High School 1 Wonomulyo in the first cycle test

\begin{tabular}{|c|c|c|}
\hline \multicolumn{2}{|c|}{ Valid } & Cycle 1 \\
\hline $\mathrm{N}$ & Missing & 36 \\
\hline & Mean & 0 \\
\hline Median & 69,4444 \\
\hline Mode & 70,0000 \\
\hline Std. Deviation & 70,00 \\
\hline Variance & 13,08094 \\
\hline Range & 171,111 \\
\hline Minimum & 60,00 \\
\hline Maximum & 30,00 \\
\hline Sum & 90,00 \\
\hline
\end{tabular}

From Table 6, it appears that from 36 students of Class 7B of State Junior High School 1 Wonomulyo who were the subject of research in Cycle I Tests it seems that; the highest score achieved by students amounted to 90 and the lowest score of 30 so that the range of values produced is 60 then based on the above data obtained an average student learning outcome is 69.44 , which means that the average students' absorption ability in receiving subject material during the first cycle learning process is in the high and completed category. The result of mode value is 70 which can be interpreted most of the 36 students have the score of learning outcomes in mathematics on the subject of the addition and subtraction of integers which are in the high category or in the completed category in the learning cycle I.

Table 7. Distribution and Percentage of Student Learning Outcomes in Grade 8B of State Junior High School 1 Wonomulyo in Cycle I Test

\begin{tabular}{|c|c|c|c|c|}
\hline \multirow{2}{*}{ No } & \multirow{2}{*}{ Score } & Category & \multicolumn{2}{|c|}{ Cycle I } \\
\cline { 4 - 5 } & & Frequency & $\begin{array}{c}\text { Percentage } \\
(\%)\end{array}$ \\
\hline 1 & $0-34$ & Very Low & 1 & 2,80 \\
\hline 2 & $35-54$ & Low & 3 & 8,40 \\
\hline 3 & $55-64$ & Moderate & 5 & 13,90 \\
\hline 4 & $65-84$ & High & 23 & 63,90 \\
\hline 5 & $85-100$ & Very High & 4 & 11,10 \\
\hline \multicolumn{3}{|c|}{ Total } & $\mathbf{3 6}$ & $\mathbf{1 0 0 \%}$ \\
\hline
\end{tabular}

The data grouping of mathematics learning outcomes' scores achieved by the students class 8B of State Junior High
School 1 Wonomulyo at the end of the first cycle test (after the learning model has been applied) into category five obtained a list of frequency distributions and percentage categories of student learning outcomes as shown in Table 7.

Frequency and percentage of test scores in mathematics learning outcomes for Class 8B students at State Junior High School 1 Wonomulyo during Cycle I.

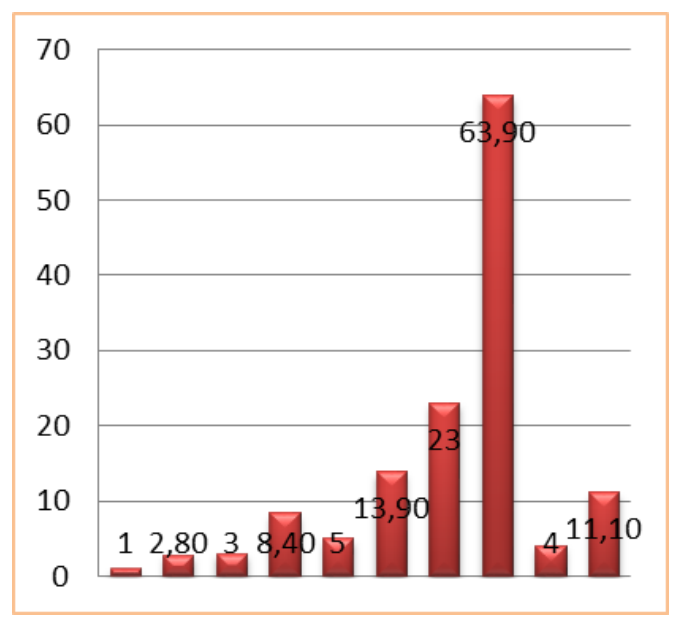

Figure 4. Distribution and Percentage of Mathematics Learning Outcomes of students Class 8B at State Junior High School 1 Wonomulyo during Cycle I Test

From Picture. 5. It appears that there is 1 student who falls into the very low category $(2.80 \%)$ of cycle I. The number of students in the low category decreased was at the time before the study there were 4 people $(11.20 \%)$, and in the first cycle there were 3 people $(8.40 \%)$. The number of students included in the medium category also decreased where at the time before the study were 13 people $(36.10 \%)$, and the first cycle were 5 students (13.90\%), while students who were in the high category experienced an increase of 2 students $(5.60 \%)$ at the time before the study, to 23 students $(63.90 \%)$ in the first cycle, as well as in the very high category also increased from no students $(0 \%)$ at the time before the study and the cycle I became 4 students $(11.10 \%)$.

Furthermore, to see the level of student learning mastery, the overall scores obtained by students are divided into two interval values in the category of mastery learning that applies in State Junior High School 1 Wonomulyo in Mathematics Subjects. The percentage and category of students' learning mastery in Class 8B of State Junior High School 1 Wonomulyo can be seen in Table 8 .

Table 8. Percentage and category of students' learning mastery in class 8B of State Junior High School 1 Wonomulyo during the first cycle test

\begin{tabular}{|c|c|c|c|c|}
\hline \multirow{2}{*}{ No } & \multirow{2}{*}{ Score } & Category & \multicolumn{2}{|c|}{ Cycle I } \\
\cline { 4 - 5 } & & & Frequency & Percentage \\
\cline { 4 - 5 } & & $\begin{array}{c}\text { Un } \\
\text { Completed }\end{array}$ & 9 & $(\%)$ \\
\hline 1. & $0-64$ & 25,10 \\
\hline 2. & $65-100$ & Completed & 27 & 75,00 \\
\hline \multicolumn{3}{|c|}{ Total } & 36 & $100 \%$ \\
\hline
\end{tabular}


For more details on the comparison of the frequency distribution and learning mastery category of students' class $8 \mathrm{~B}$ at State Junior High School, 1 Wonomulyo during the first cycle can be seen in Figure 5.

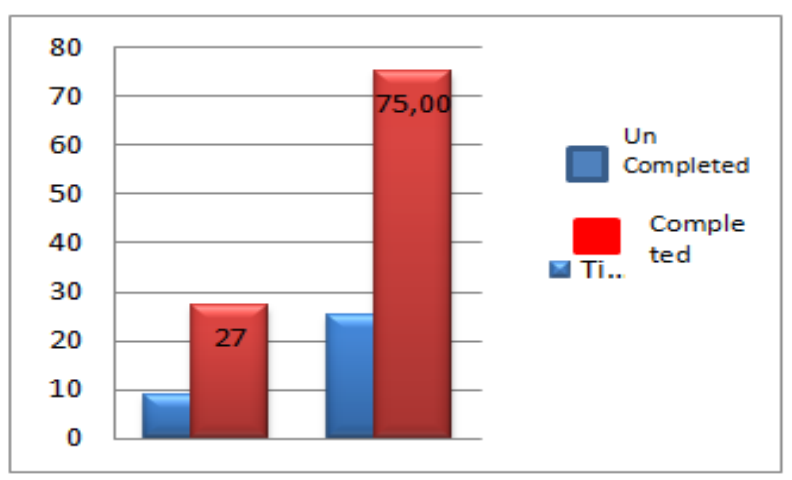

Figure 5. Bar Diagram of Percentage and mastery category of Mathematics learning outcomes of students Class 8B at State Junior High School 1 Wonomulyo during the first cycle test

From Figure 4, it appears that from 36 students of Class 8B at State Junior High School 1 Wonomulyo who became the study sample, can be described as follows:

a. The percentage of students' learning mastery before being taught through the implementation of ICARE learning model with the application of concept maps for the completed category was $5.60 \%$ ( 2 people), then after being taught with the use of the Beads model Props increased to $75.00 \%$ (27 people),

b. The percentage of students' learning mastery before being taught through the ICARE learning model with the application of concept maps, for the uncompleted category was $94.52 \%$ (34 people), then after being taught with the use of the ICARE learning model with the application of the concept map decreased to $25.10 \%$ (9 person).

This shows that the number of students in the completed category had increased to 2 people or $5.60 \%$ at the time before the study and increased to 27 people or $75.00 \%$ in Cycle I. Although it has grown from before but it still has not met the Indicators of Achievement Research in State Junior High 1 Wonomulyo which should be $80 \%$ of the total number of students.

Based on the results of qualitative and quantitative analysis, it is seen that basically the implementation of learning through the use of ICARE learning models with the application of concept maps is an increase from the Initial Test to the first cycle, then based on the results of student observations in the first cycle it is known that through learning with ICARE learning models with concept maps can activate students even though the increase is still small, the percentage of students who respond to Teacher's questions is still relatively low, this is influenced by the lack of confidence of students to perform in front of the class. Furthermore, the percentage of students who carry out other activities when discussing the subject matter is still high.
Other factors that cause students to have grades that are still very low, low and moderate, among others:

(a) The learning process is too fast when giving subject matter.

(b) Lack of classroom management and lack of guidance in working on individual questions so students tend to do other activities during the learning process.

The steps as a result of reflection on cycle I in the implementation of cycle II include:

(a) The process of teaching and learning is not too fast.

(b) Change the composition of students' chairs back as before

(c) Provide guidance to students, especially those who are serious if the teacher is taking turns in giving pointers.

(d) Provide opportunities for students who are less participating and are always playing around to work on the board.

(e) Provide the motivation to students by suggesting that students who often provide solutions to questions given by the teacher, and who often go up to the blackboard working on the problems will get extra score.

\subsubsection{Discussion and Presentation of Analysis Results of} Learning Tests Data in Cycles II

From the results of Mathematics learning outcomes analysis of Class 8B students of State Junior High School, 1 Wonomulyo in the Cycle II test can be seen in Table 9 . below.

Table 9. Statistics Learning Outcomes Students Class 8B State Junior High School 1 Wonomulyo in Cycle Test II

\begin{tabular}{|c|c|c|}
\hline & & Cycle 2 \\
\hline \multirow[t]{2}{*}{$\mathrm{N}$} & Valid & 36 \\
\hline & Missing & 0 \\
\hline \multicolumn{2}{|c|}{ Mean } & 80,2778 \\
\hline \multicolumn{2}{|c|}{ Median } & 80,0000 \\
\hline \multicolumn{2}{|c|}{ Mode } & 80,00 \\
\hline \multicolumn{2}{|c|}{ Std. Deviation } & 11,82881 \\
\hline \multicolumn{2}{|c|}{ Variance } & 139,921 \\
\hline \multicolumn{2}{|c|}{ Range } & 50,00 \\
\hline \multicolumn{2}{|c|}{ Minimum } & 50,00 \\
\hline \multicolumn{2}{|c|}{ Maximum } & 100,00 \\
\hline \multicolumn{2}{|c|}{ Sum } & 2890,00 \\
\hline
\end{tabular}

From Table 9, it appears that from 36 students of Class 8B of State Junior High School 1 Wonomulyo who are the subjects of research in Cycle II, it seems that; the average scores that students obtained are 80.27, and the highest score is 100 . Then for the lowest score is 50.00 , and obtained a range of 50 shows that the ability of students is even and the standard deviation of 11.82. If the entire scores obtained are converted on a scale of five, then it can be seen as in table 10 the following. 
Table 10. Distributions and Percentage of Learning Outcomes Students Class 8B at State Junior High School 1 Wonomulyo on the Cycle Test II

\begin{tabular}{|c|c|c|c|c|}
\hline \multirow{2}{*}{ No } & \multirow{2}{*}{ Score } & \multirow{2}{*}{ Category } & \multicolumn{2}{|c|}{ Cycle II } \\
\cline { 4 - 5 } & & & Frequency & Percentage (\%) \\
\hline 1 & $0-34$ & Very Low & 0 & 0,00 \\
\hline 2 & $35-54$ & Low & 2 & 5,60 \\
\hline 3 & $55-64$ & Moderate & 0 & 0,00 \\
\hline 4 & $65-84$ & High & 23 & 63,90 \\
\hline 5 & $85-100$ & Very High & 11 & 30,50 \\
\hline \multicolumn{3}{|r|}{ Total } & $\mathbf{3 6}$ & $\mathbf{1 0 0 \%}$ \\
\hline
\end{tabular}

Frequency and percentage of test scores of mathematics learning outcomes for students Class 8B of State Junior High School 1 Wonomulyo Cycle II. For more details, see the following figure.

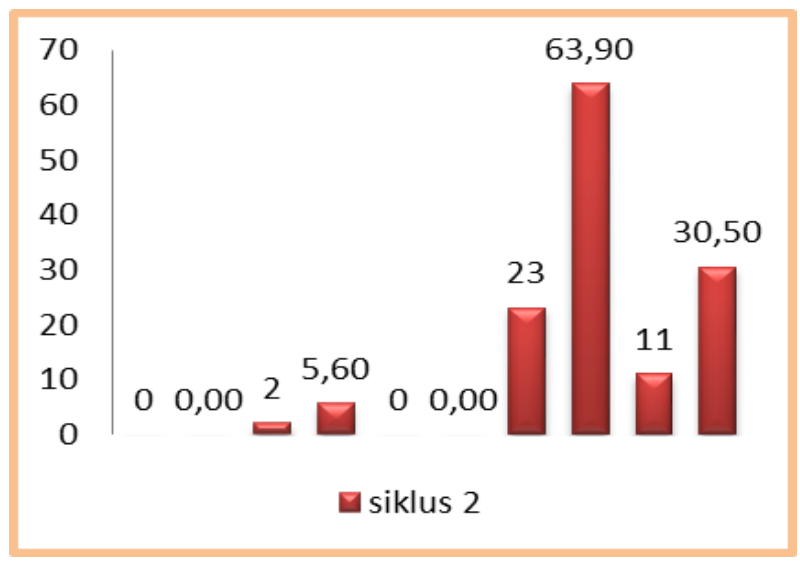

Figure 6. Distribution and Percentage of Mathematics Learning Outcomes students Class 8B at State Junior High School 1 Wonomulyo during the cycle II

From Figure 6, it appears that those who fall into the very low category $(0 \%)$ in the second cycle, the number of students who fall into the low category has decreased in the low category, i.e. there are only two people $(5.60 \%)$ in the second cycle. Then the number of students included in the medium category also decreased so that it became nonexistent $(00.00 \%)$, while students who entered the high group increased to 23 people $(63.90 \%)$ in the second cycle, as well as in the very high category also increased by 11 people (30.50\%).

Table 11. Percentage and category of mastery learning for students Class $8 \mathrm{~B}$ of State Junior High School 1 Wonomulyo in the Cycle II

\begin{tabular}{|c|c|c|c|c|}
\hline \multirow{2}{*}{ No } & \multirow{2}{*}{ Score } & \multirow{2}{*}{ Category } & \multirow{2}{*}{ Cycle II } \\
\cline { 4 - 5 } & & & Frequency & Percentage \\
\cline { 4 - 5 } & & & 2 & 5,60 \\
\hline 1. & $0-64$ & Un completed & 34 & 94,40 \\
\hline 2. & $65-100$ & Completed & 34 & $\mathbf{1 0 0 \%}$ \\
\hline \multicolumn{3}{|c|}{ Total } & $\mathbf{3 6}$ & \\
\hline
\end{tabular}

Furthermore, to see the mastery of student learning, the overall scores obtained by students are divided into two interval values in the category of mastery learning that applies in State Junior High School 1 Wonomulyo for Mathematics Subjects. The percentage and category of mastery learning for students Class 8B at State Junior High School 1 Wonomulyo can be seen in Table 11.

For more details on the comparison of the frequency distribution and learning mastery categories of students, Class 8B at State Junior High School 1 Wonomulyo during cycle II can be seen in the graph as follows.

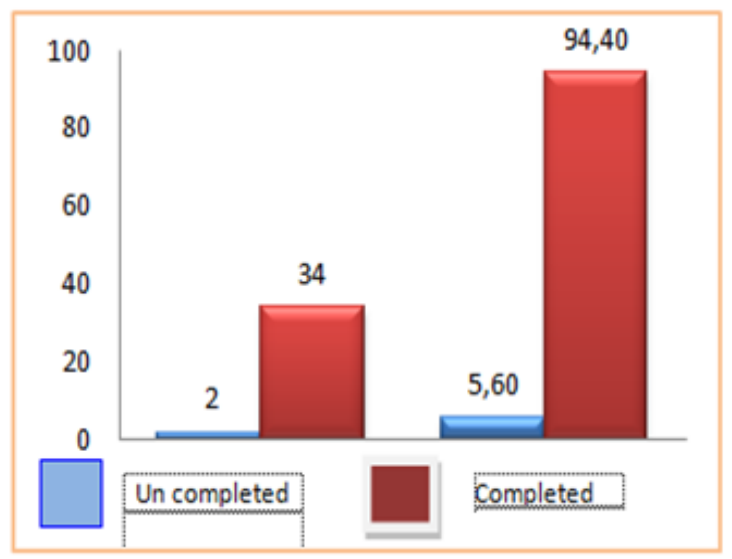

Figure 7. Mastery categories of Mathematics learning outcomes for students Class 8B at State Junior High School 1 Wonomulyo during the cycle II

From Figure 7, it appears that from 36 students of Class 8B of State Junior High School 1 Wonomulyo, who became the study sample can be described as follows:

a. The percentage of students' learning mastery before being taught through the implementation of the ICARE learning model with the application of concept maps for the completed category increased to $94.40 \%$ (34 people).

b. The percentage of students' learning mastery before being taught through the application of the ICARE learning model with the implementation of concept maps for the uncompleted category decreased to $5.60 \%$ ( 2 people) in the cycle II.

This shows that the number of students in the complete category had increased, i.e., two people or $5.60 \%$ at the time before the study and increased to 27 people or $75.00 \%$ in Cycle I then increased again to 34 people or $94.40 \%$ in Cycle II. This study shows that the increase has exceeded the indicator of research achievement in State Junior High School 1 Wonomulyo, which is $80 \%$ of the total number of students.

Cycle II was carried out after reflecting on the implementation of cycle I, then a description of the actions taken in cycle II was obtained as an improvement from the implementation of cycle I, so that the learning outcomes obtained in cycle II increased.

The frequency of students 'attendance during the teaching 
and learning activities until the end of the second cycle meeting illustrates that students' interest and motivation to learn mathematics have increased, the courage to propose to work on the board is evenly distributed not only to the class of students who have good learning outcomes, but silent students showed courage to go forward to work on exercises on the board.

The form of changes in actions taken in cycle II is where in Cycle I the teacher changes the seat shape of students to form the letter U, but in Cycle II the teacher returns the seat position as usual and then allows students to ask questions. Another thing to do is the teaching and learning process that is not too fast, provides opportunities for students who are less participating and always play around to work on the board, especially those who are serious if the teacher who guides in turns gives sanctions to students who act less positively like ask the student to reiterate what has been explained by the teacher or in the form of reprimand questions so that the student is more focused on the material provided, as well as providing motivation to students by suggesting that students often offer solutions to questions given by the teacher and often going up to work on the blackboard will get extra score. In general, in cycle II there was a definite increase in student activity, this can be seen from the average attendance of students at each meeting, the number of students who volunteered to work on problems with teaching props on the board, students who answered when getting asked questions about subject material, by contrast the number of students doing other activities when discussing subject material is decreasing. During the implementation of activities in the cycle II, researchers have tried to make changes for the improvement of mathematics learning outcomes in the implementation of ICARE learning models with the application of concept maps and research results in cycle II showed improvement from the previous cycle and the results obtained have reached the indicators of success as targeted by the researcher.

From the results of the reflection here it can be concluded that there has been an increase in mathematics learning outcomes, in addition to that the activeness of students in the teaching and learning process also increased after implementing the ICARE learning model with a concept map.

\section{Conclusions}

Based on the analysis and discussion of research results with teaching actions, namely the use of the ICARE learning model with a concept map conducted on students class 8B of State Junior High School 1 Wonomulyo, it can be concluded that the average scores of mathematics learning outcomes achieved by students on the initial test is 41.17 with the category low which increased in Cycle I to 69.44 with a high category and increased again in Cycle II to 80.27 with a high category. Thus, mathematics learning outcomes on the subject of Solid Geometry Shapes achieved by students of class 8B, State Junior High School 1 Wonomulyo have improved after going through the learning process by using the learning model. From the research results obtained, it is expected that teachers pay attention and use learning models in the learning process especially mathematics material to make students more active so that the concepts received by students become more meaningful.

\section{Acknowledgements}

This work was supported by the research team at the Research Laboratory of the University of Al Asyariah Mandar, and Ministry of Research, Technology and Higher Education of Republic Indonesia under F. Number 115/SP2H/LT/DRPM/2019, 79/UNASMAN/AK/2019.

\section{REFERENCES}

[1] R. Badjeber, "Penerapan Metode Penemuan Terbimbing Untuk Meningkatkan Hasil Belajar Siswa Kelas VII Ki Hajar Dewantoro SMP Negeri 4 Palu Pada Materi Hubungan Antar Sudut," Skripsi Sarj. pada FKIP Univ. Tadulako Palu, 2011.

[2] M. Klein, "How is it that learning mathematics in the early years can become so difficult? a post-structuralist analysis," Contemp. Issues Early Child., vol. 8, no. 4, pp. 313-319, 2007.

[3] C. Suurtamm et al., Assessment in mathematics education: Large-scale assessment and classroom assessment. Springer, 2016.

[4] F. Febryanti, "PENINGKATAN HASIL BELAJAR MATEMATIKA MELALUI METODE PEMBELAJARAN MIND MAPPING DENGAN PENDEKATAN CONTEXTUAL TEACHING AND LEARNING," Pepatudzu Media Pendidik. dan Sos. Kemasyarakatan, vol. 12, no. 1, pp. 14-22, 2017.

[5] M. Çakmak, "An examination of concept maps created by prospective teachers on teacher roles," Procedia-Social Behav. Sci., vol. 2, no. 2, pp. 2464-2468, 2010.

[6] S. L. Battersby and B. Verdi, "The culture of professional learning communities and connections to improve teacher efficacy and support student learning," Arts Educ. Policy Rev., vol. 116, no. 1, pp. 22-29, 2015.

[7] E. Wenger, "Communities of practice and social learning systems: the career of a concept," in Social learning systems and communities of practice, Springer, 2010, pp. 179-198.

[8] Basri, M. Siddiq, R. Tamin, and S. Azis, "Data Mining Technique as Majors Support System Management with Classification Approach," J. Phys. Conf. Ser., vol. 1244, p. 12004, Jun. 2019.

[9] B. Hoffman and D. Ritchie, "Teaching and learning online: 
Tools, templates, and training," in Society for Information Technology \& Teacher Education International Conference, 1998, pp. 119-123.

[10] H. U. Jusmawati and M. Darwis, "Efektivitas Penerapan Model Berbasis Masalah Setting Kooperatif dengan Pendekatan Saintifik dalam Pembelajaran Matematika di Kelas X SMA Negeri 11 Makassar," Daya Mat. J. Inov. Pendidik. Mat., vol. 3, no. 1, pp. 30-40, 2015.

[11] S. A. A. El-Hay, S. E. El Mezayen, and R. E. Ahmed, "Effect of concept mapping on problem solving skills, competence in clinical setting and knowledge among undergraduate nursing students,” J. Nurs. Educ. Pract., vol. 8, no. 8, pp. 34-46, 2018.

[12] N. Sudjana, Pembinaan dan pengembangan kurikulum di sekolah. Sinar Baru, 1989.

[13] D. Arikunto Suharsimi, "Penelitian Tindakan Kelas.” Jakarta: Bumi Aksara, 2006.

[14] M. Jaafarpour, S. Aazami, and M. Mozafari, "Does concept mapping enhance learning outcome of nursing students?," Nurse Educ. Today, vol. 36, pp. 129-132, 2016.

[15] I. Sen Singh and K. Moono, "The Effect of Using Concept Maps on Student Achievement in Selected Topics in Chemistry at Tertiary Level.," J. Educ. Pract., vol. 6, no. 15, pp. 106-116, 2015. 